\title{
Assessing Systemicity of Peanut Fungicides Through Bioassay of Plant Tissues with Sclerotium rolfsii
}

\author{
J. Augusto and T. B. Brenneman, Department of Plant Pathology, University of Georgia Coastal Plain Experiment Station, Tifton
} 31793

\begin{abstract}
Augusto, J., and Brenneman, T. B. 2012. Assessing systemicity of peanut fungicides through bioassay of plant tissues with Sclerotium rolfsii. Plant Dis. $96: 330-337$.

To better understand movement of systemic fungicides in peanut (Arachis hypogaea), three terminal, fully expanded leaves of primary lateral branches of 'Tifrunner' peanut were treated with prothioconazole + tebuconazole (Provost, $0.29 \mathrm{~kg}$ a.i./ha), azoxystrobin (Abound, $0.31 \mathrm{~kg}$ a.i./ha), or flutolanil (Moncut, $0.79 \mathrm{~kg}$ a.i./ha) in field experiments. Basipetal leaves and pods on the same branch with the treated leaves were sequentially numbered from 1 to 3 , with 1 being closest to treated foliage. These nontreated tissues, with newly formed terminal leaves, were sampled 4, 8, and 12 days after treatment for bioassay with Sclerotium rolfsii. All fungicides protected new acropetal leaves while

prothioconazole + tebuconazole also provided some inhibition of $S$ rolfsii in nontreated basipetal leaves but no fungicide protected pods. In the greenhouse, applications of prothioconazole + tebuconazole or prothioconazole (Proline, $0.18 \mathrm{~kg}$ a.i./ha) to main stems of 'Georgia Green' provided some protection to leaves from nontreated cotyledonary branches sampled 14 days after last treatment but $S$. rolfsii was not inhibited on nontreated roots, stems, or pods. The results demonstrate acropetal protection by all fungicides evaluated, and indicate that prothioconazole + tebuconazole or prothioconazole applied to foliage can sometimes reduce diseases in the lower, nontreated portions of the plant.
\end{abstract}

Basipetal movement of some fungicidal compounds or their active derivatives occurs in the phloem sap in the symplast sieve tubes $(9,11,39)$. Most fungicides cannot move this way, although it is a desirable attribute to improve control of soilborne diseases. This is particularly true for a crop like peanut which forms a dense canopy of leaves and is susceptible to several important diseases that occur belowground or at the soil surface. In peanut, the canopy of most commercial runner cultivars closes within 2 months after emergence, when fungicide applications for soilborne diseases are initiated. Fungicide spray penetration of the canopy to the lower stems, roots, pegs, and pods, where infection of soilborne pathogens initially occurs, is difficult due to the overlapping layers of the peanut leaves $(1,2)$. Peanut growers are aware of this and take steps to compensate for it, including applying fungicides at night, when the leaves are folded $(1,2)$, and applying irrigation soon after fungicide application to physically wash fungicide residues off the leaves to the lower parts of the plant (42).

Alternatively, systemic fungicides with basipetal movement could effectively target soilborne pathogens by moving downward in the plant after a foliar application. For this to occur, fungicide applied to a leaf will need to permeate into, and diffuse through, the cuticle. It must then permeate into the xylem apoplast and the symplast membrane into the sieve tubes at the site of leaf application, and then move basipetally with the assimilates $(28,29)$.

The fungicide permeation into the xylem apoplast at the site of leaf application is associated with its lipophilicity or relative solubility to plant membranes (29). Fungicide lipophilicity is defined as the partition coefficient between a plant membrane and an aqueous environment. Octanol and water, respectively, are suitable

Corresponding author: J. Augusto, E-mail: jaugusto@uga.edu

Accepted for publication 6 September 2011.

http://dx.doi.org/10.1094/PDIS-04-11-0303

(C) 2012 The American Phytopathological Society surrogates for this purpose (29). Therefore, the octanol-water coefficient $\left(\mathrm{K}_{\mathrm{ow}}\right)$ is defined as the concentration of the fungicide added to the octanol-water system partitioning into the octanol phase relative to that into the water phase (29). Quantitatively, lipophilicity is expressed as a logarithm of $\mathrm{K}_{\mathrm{ow}}$ value $\left(\log \mathrm{K}_{\mathrm{ow}}\right)$. Aromatic hydrocarbon, morpholine, and dinitrophenyl crotonate groups contain some of the most lipophilic fungicides with $\log \mathrm{K}_{\mathrm{ow}}$ values of 4 to 6.5 . Conversely, fungicides belonging to dithiocarbamate, phosphonate, acylalanine, and antibiotics with fungicide action groups are generally hydrophilic or low lipophilic $\left(\log \mathrm{K}_{\mathrm{ow}}\right.$ of -7.5 to $<2$ ). Most of the peanut fungicides currently used for control of soilborne diseases in Georgia are demethylation inhibitors (DMIs; e.g., tebuconazole), quinone outside Inhibitors (e.g., azoxystrobin), or carboxamides (e.g., flutolanil). They all have intermediate $\log \mathrm{K}_{\mathrm{ow}}$ values. Permeation of lipophilic compounds through the cuticle is rapid overall but very lipophilic compounds may be retained in the leaf waxes, delaying the diffusion into the apoplast. Very hydrophilic compounds are also partitioned slowly from the cuticle into the apoplast $(16,23,43)$.

The fungicides that reach the xylem apoplast in the leaf zone at the site of application are, in principle, also capable of permeating into the phloem sieve tubes. Nevertheless, fungicides entering the phloem may also leak back to the xylem and move with the transpiration stream. The concentration of a fungicide in the phloem partially depends upon its ability to permeate symplast membranes into sieve tubes within the leaf zone while its efflux to the apoplast is limited (28). Systemic studies, especially with herbicides, have shown that the ability of a pesticide to concentrate in the phloem symplast, and move for long-distances, is mostly related to its acid strength $(8,15,19,34,40)$. The acid strength is measured as the negative logarithm, $\mathrm{pK}_{\mathrm{a}}$, of acid dissociation constant, $\mathrm{K}_{\mathrm{a}}(40)$. The xylem apoplast has an acidic to neutral $\mathrm{pH}$ (approximately 6) while the phloem symplast is alkaline ( $\mathrm{pH}$ of approximately 8$)(7,17)$. A pesticide with $\mathrm{pK}_{\mathrm{a}}$ value less than 7 is, in general, considered acidic (29). Therefore, acidic fungicides permeating into the sieve tubes will be subjected to dissociation (34). The dissociated derivatives are generally less lipophilic and 
more polar than their undissociated forms, and leakage out of the sieve tubes is substantially restricted $(15,34,43)$. The $\log \mathrm{K}_{\mathrm{ow}}$ values of phloem mobile and ambimobile compounds are $\mathrm{pH}$ dependent, being higher in acidic apoplast and lower in the alkaline symplast environment. The $\log \mathrm{K}_{\mathrm{ow}}$ values of xylem systemic compounds are independent from the proton concentration (34). Most weak acidic pesticides of intermediate lipophilicity are reported to have phloem mobility because they are retained longer within the phloem sieve tubes $(8,43)$.

For a fungicide, the metabolic change occurring in the phloem sieve tubes from an undissociated lipophilic form to a dissociated derivative with a decreased lipophilicity could result in loss or decrease of biological activity against the intended fungal pathogen. Most fungicides have neither acidic nor basic properties. Nevertheless, fosetyl-Al, a weak acidic $\left(\mathrm{pK}_{\mathrm{a}}=4.7\right)$ phosphonate fungicide with $\log \mathrm{K}_{\mathrm{ow}}$ of -2.1 , is phloem mobile $(9,39)$ and effective against oomycete-incited diseases (12).

In peanut, prothioconazole is a relatively new fungicide with intermediate lipophilicity $\left(\log \mathrm{K}_{\mathrm{ow}}=3.82\right)$ and weak acidity $\left(\mathrm{pK}_{\mathrm{a}}=\right.$ 6.9) (Table 1) which could, theoretically, confer some phloem mobility. In plants, the prothioconazole-desthio metabolite is nonacidic with intermediate lipophilicity $\left(\log \mathrm{K}_{\mathrm{ow}}=3.04\right)$ but prothioconazole is the only moiety listed as biologically active for the control of plant diseases. Prothioconazole is registered in a DMI mixture with tebuconazole for the control of peanut soilborne and foliar diseases (25). Prothioconazole is also available as a solo active ingredient in Proline, which is registered for use in peanut as an in furrow spray for suppression of Cylindrocladium black rot, caused by the root-infecting pathogen Cylindrocladium parasiticum $(6,18,38)$.

The objective of this study was to determine the relative acropetal and basipetal protection of nontreated portions of peanut plants by several foliar-applied fungicides commonly used on peanut for control of stem rot caused by Sclerotium rolfsii. Field and greenhouse studies are included, and the fungicide residues quantified by bioassay with $S$. rolfsii.

\section{Materials and Methods}

Field trials. 'Tifrunner' peanut (21) was seeded with a two-row Monosem planter at 23 seeds/m on 16 May 2007 at the Rigdon Farm, University of Georgia Tifton Coastal Plain Experiment Station. The soil type was Tifton loamy sand, 2 to $5 \%$ slope, and the previous crop was peanut. The field was bottom plowed to a depth of 20 to $25 \mathrm{~cm}$, disk harrowed, and marked off in plots $1.83 \mathrm{~m}$ wide. Preemergence herbicides ethalfluralin $(0.72 \mathrm{~kg}$ a.i./ha, Sonalan; Dow AgroSciences, Indianapolis, IN) and S-metolachlor (1.5 kg a.i./ha, Dual Magnum; Syngenta Crop Protection, Inc., Greensboro, NC) were applied and incorporated with a rototiller within the upper $5 \mathrm{~cm}$ of soil a week before peanut was seeded. The plots had two rows $0.91 \mathrm{~m}$ apart and were $7.62 \mathrm{~m}$ long. The nematicide aldicarb (1.68 kg a.i./ha, Temik 15G; Bayer CropScience, Research Triangle Park, NC) was applied on a 0.3-m band at seeding. The postemergence herbicide imazapic $(0.07 \mathrm{~kg}$ a.i./ha, Cadre 70 DG; BASF Corp., Research Triangle Park, NC) was applied about 40 days after seeding. Gypsum $(1,120 \mathrm{~kg} / \mathrm{ha})$ was applied at beginning pod (4) in a 50-cm band over the rows without soil incorporation to supplement calcium in the soil. All plots were coversprayed with protectant fungicide chlorothalonil $(1.26 \mathrm{~kg}$ a.i./ha, Bravo WeatherStik, Syngenta Crop Protection Inc.) at 187 liters/ha (LPH) applied with a conventional tractor-mounted sprayer using three $\mathrm{D}_{2-13}$ nozzles per row to prevent infection and defoliation by leaf spot pathogens (14). Chlorothalonil has no significant field activity on $S$. rolfsii (14), a peanut pathogen used later in this study to bioassay plant tissues.

The experimental design used was a balanced repeated-measures with treatments replicated 10 times. The experiment was concomitantly repeated. The grouping factor was fungicide treatment at 100 days after seeding in a randomized complete block design. The top three fully expanded leaves from the primary lateral stem next to the soil were dipped for $30 \mathrm{~s}$ in a fungicide suspension of prothioconazole + tebuconazole $(0.29 \mathrm{~kg}$ a.i./ha, Provost $433 \mathrm{SC}$; Bayer CropScience), azoxystrobin (0.31 kg a.i./ha, Abound 2.08 F; Syngenta Crop Protection, Inc.), flutolanil (0.79 kg a.i./ha, Moncut 70 WP; Nichino America, Inc., Wilmington, DE), or water (nontreated control). All fungicides were diluted in water at $190 \mathrm{LPH}$ equivalent. The leaves below the treated area were sequentially numbered from 1 to 3, with 1 being the closest to the treated foliage (Fig. 1). The repeated measures were sampling dates at 4,8 , and 12 days after the fungicides were applied.

At each sampling date, 10 numbered leaves per treatment (e.g. leaf position versus fungicide) and stems below the fungicidetreated area were collected for bioassay with $S$. rolfsii in the laboratory to determine fungicide basipetal protection (22). At the day-12 sampling, pods from the stems with treated leaves and the new leaves that expanded after treatment were collected and also bioassayed with $S$. rolfsii to determine basipetal and acropetal protection, respectively. Pods were also sequentially numbered from 1 to 3, with 1 being the closest to fungicide-treated foliage (Fig. 1). Additionally, leaves, stems, and pods (20 each) were treated with fungicides or water in the field as described previously. After drying, these tissues were taken to the laboratory for bioassay with $S$. rolfsii on the same day to establish a baseline level of control with full fungicide rates.

Greenhouse trials. The experiments were conducted in the greenhouse at the University of Georgia Coastal Plain Experiment Station, Tifton, in 2008 to evaluate fungicide basipetal protection in 'Georgia Green' peanut plants (5). Peanut was seeded and grown in pots $(20 \mathrm{~cm}$ in diameter by $14 \mathrm{~cm}$ in height) and small containers ( $4 \mathrm{~cm}$ in diameter by $20.5 \mathrm{~cm}$ in height). Plants were grown in a compressed, general-purpose peat-based medium consisting of Canadian sphagnum peat moss ( 75 to $85 \%$ by volume), endomycorrhizal inoculum (Glomus intraradices), perlite (horticultural grade), vermiculite (horticultural grade), dolomitic and calcitic limestone ( $\mathrm{pH}$ adjuster), and wetting agent (Premier Horticulture Inc., Quakertown, PA).

Both pot and container experiments were in a balanced randomized complete block design with seven replications and were repeated. Peanut for the first and second tests was seeded on 10 December 2007 and 23 January 2008, respectively. Several seeds were planted in each container and thinned to leave one plant per pot. The fungicide treatments were based on commercially used spray programs and consisted of four applications of prothioconazole ( $0.18 \mathrm{~kg}$ a.i./ha, Proline $480 \mathrm{SC}$; Bayer CropScience), prothioconazole + tebuconazole (0.29 kg a.i./ha, Provost $433 \mathrm{SC}$; Bayer

Table 1. Physical properties of four peanut fungicides

\begin{tabular}{|c|c|c|c|}
\hline Fungicide & Lipophilicity $\left(\log K_{o w}\right)^{x}$ & Acidity $\left(\mathbf{p K}_{\mathrm{a}}\right)^{\mathrm{y}}$ & Reference \\
\hline Prothioconazole & $4.16(\mathrm{pH} 4), 3.82(\mathrm{pH} 7), 2.0(\mathrm{pH} 9)$ & 6.9 & 35 \\
\hline Tebuconazole & $3.70^{\mathrm{z}}$ & N/A & $9,26,33,36$ \\
\hline Azoxystrobin & $2.50^{\mathrm{z}}$ & N/A & 33 \\
\hline Flutolanil & $3.70^{\mathrm{z}}$ & N/A & 30 \\
\hline
\end{tabular}




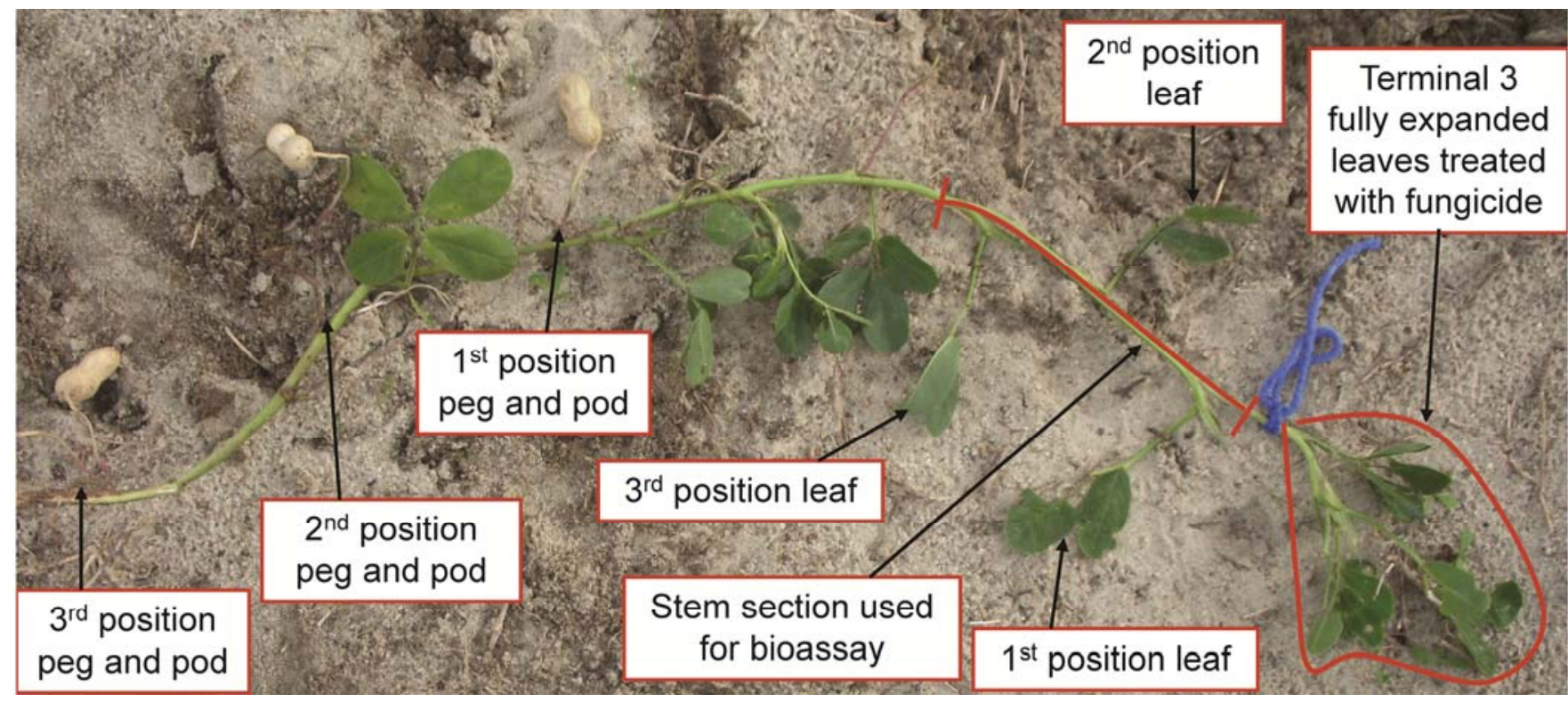

Fig. 1. Main lateral branch of 'Tifrunner' peanut grown in the field, indicating the fungicide-treated top foliage and the nontreated tissues below sampled for bioassay with Sclerotium rolfsii. Leaves and stem were sampled at 4,8 , and 12 days after treatment while the pods were only collected 12 days after treatment.

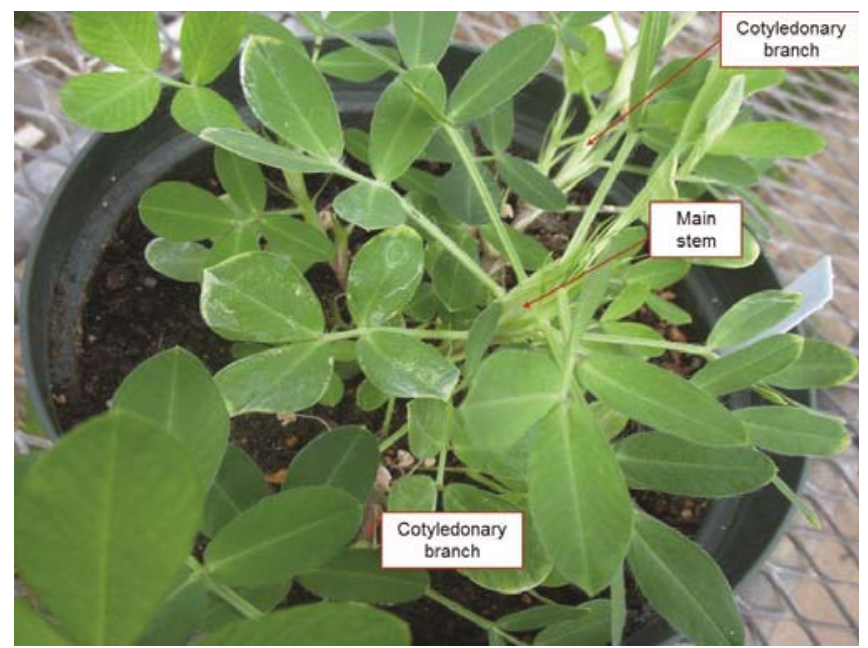

Fig. 2. Potted peanut 'Georgia Green' grown in greenhouse showing the main stem foliage treated with fungicide and cotyledonary branches from which plant tissues were sampled for a bioassay with Sclerotium rolfsii.

CropScience), tebuconazole (0.21 kg a.i./ha, Folicur 3.6 F; Bayer CropScience), or two applications of azoxystrobin $(0.31 \mathrm{~kg}$ a.i./ha, Abound 2.08 F; Syngenta Crop Protection, Inc.) or flutolanil (0.79 $\mathrm{kg}$ a.i./ha, Moncut $70 \mathrm{WP}$; Nichino America, Inc.) and a nontreated control. To selectively apply fungicide only to the main stems, plants were inverted and foliage on the main stem above the cotyledonary branches was immersed in a 190-LPH mix of fungicide for $5 \mathrm{~s}$. After dipping, the plants remained inverted until the fungicide residue had dried (Fig. 2), and they received no top watering that could potentially move fungicide residues. The first fungicide applications were at 40 days after planting and were repeated at 14-day intervals for four-spray programs and 28-day intervals for two-spray programs.

The number of expanded leaves on each plant was counted on the date of treatment. Leaves from the lower one-third or upper one-third of the nontreated cotyledonary branches, stems from cotyledonary branches, and the primary roots from the small containers were sampled 14 days after the last treatment for bioassay in the laboratory with $S$. rolfsii. In addition to the cotyledonary leaves and stems, other plant portions such as tap roots, pegs, and pods were also collected from plants grown in pots for bioassay

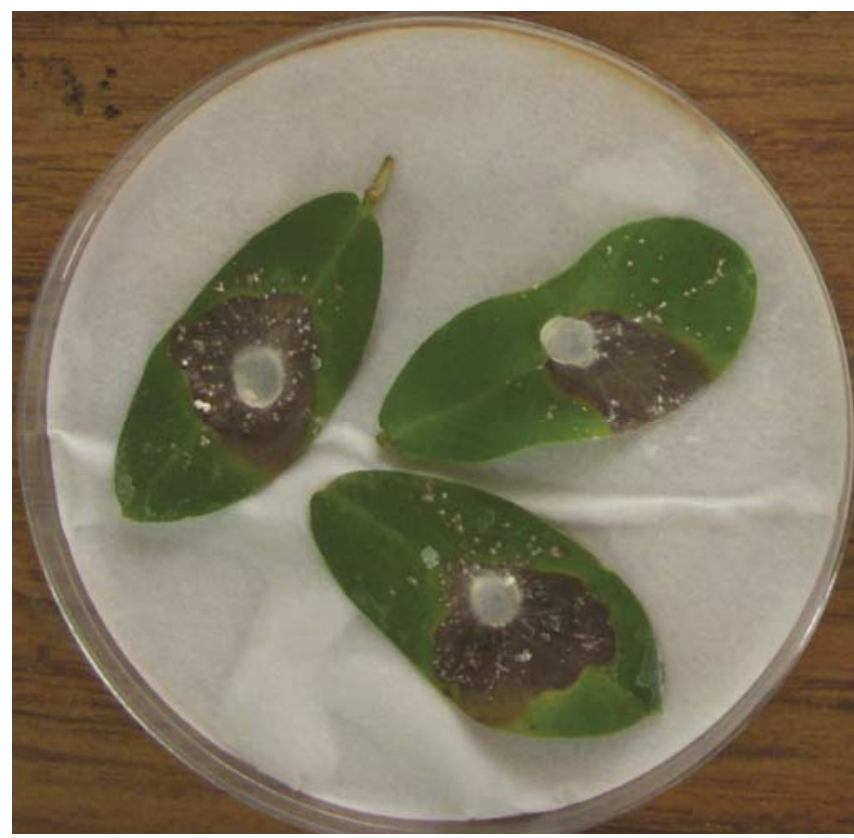

Fig. 3. Bioassay of peanut leaflets with mycelial plugs of Sclerotium rolfsii. Necrotic leaf area was visually estimated for each leaflet from 1 to 7 days after inoculation.

with $S$. rolfsii approximately 120 days after seeding at near physiological maturity.

Laboratory bioassay. Plant tissues sampled in the field were placed in resealable plastic bags and transported to the laboratory in a cooler. Field and greenhouse samples were inoculated on the same day of collection with potato dextrose agar mycelial plugs (4 $\mathrm{mm}$ in diameter) taken from the periphery of a 3-day-old actively growing culture of $S$. rolfsii, isolate SR-18, originally isolated from peanut. Both Tifrunner and Georgia Green peanut are susceptible to $S$. rolfsii. Three leaflets or a single stem, root, or attached podpeg from each treatment were placed on moistened Whatman number 2 filter paper inside a petri dish. A mycelial plug was aseptically placed either with the mycelium down on the middle of each leaflet (Fig. 3), at the pod-peg joint, or in contact with the proximal end of each stem or root relative to the treated area. Inoculated plant tissues were kept from 4 to 7 days, or longer, at room temperature $\left(25\right.$ to $\left.28^{\circ} \mathrm{C}\right)$ for daily assessments on length of necrotic 
stem, percent necrotic leaf area, length of mycelial colonization of roots, pod-pegs, as well as sclerotial counts at 28 days after inoculation on stems, roots, and pods. The percent necrotic leaf area was visually estimated, always with the same rater, to ensure reproducibility. Surface mycelial growth was measured on roots and pods attached to pegs due to difficulties in visualizing necrosis on those tissues.

Statistical analysis of the field experiments. The mixed procedure (PROC MIXED) of SAS (version 9.1; SAS Institute, Cary, NC) was used to model the covariance structure of the repeated measures on percent necrotic stem and percent necrotic leaf area by invoking the REPEATED statement. Fungicide and sampling date were included in the MODEL statement because they were considered fixed. The covariance structure associated with sampled plant tissue type (e.g., stem, leaf position 1, leaf position 2, and leaf position 3 ) included random variation aspects. Two covariance models, specifically unstructured (un) and compound symmetry (cs), were fitted for the model that minimized Akaike Information Criterion (AIC), AIC Corrected (AICC), and Bayesian Information Criterion (BIC). The models were compared by varying the 'type' option, with either un or cs, in the REPEATED statement to obtain the AIC, AICC, and BIC. The MODEL statement incorporated fungicide, sampling date, and fungicide $\times$ sampling date interaction. The REPEATED statement incorporated sampling date, sampled plant tissue type (by fungicide) for the 'subject' option, and un or cs for the 'type' option. According to the goodness of fit of the covariance structure in the 'fit statistics' outputs, the unstructured model best minimized the AIC, AICC and BIC, and provided the best fit for data analysis compared with compound symmetry. The unstructured model was then selected for further data analysis. The fungicide (by sampled plant tissue type) and sampling date effects were assessed by using the generalized least-squares means.

Data from plant tissues only sampled once, such as the new expanded leaves after fungicide treatment or the pods, pegs, and leaves and stems collected for fungicide sensitivities, were analyzed in a randomized complete block design with PROC MIXED of SAS (version 9.1).

Statistical analysis of the greenhouse experiments. Data on the number of fully expanded leaves after last treatment; percent necrotic leaf area; percent necrotic stem; length of mycelial colonization of the main root; pod-pegs; and sclerotial counts on stems, roots, and pods were subjected to statistical analysis using the PROC MIXED of SAS software (version 9.1) in a randomized block design.

\section{Results}

Field trials. The statistical analysis outputs of all dependent variables indicated no significant experiment-treatment interactions. Data of the two replicated experiments were combined. The fungicide-sampling date interaction was significant for the sampled plant tissue type $(P=0.009)$. There were also significant differences among fungicides on percent necrotic leaf area of nontreated new leaves expanding from the top fungicide-treated foliage $(P=0.001)$ but differences on mycelium colonization below pods and pegs were minimal.

The sensitivity assays indicated that prothioconazole + tebuconazole, azoxystrobin, and flutolanil were biologically active against $S$. rolfsii following inoculation with mycelial plugs on the fungicide-treated peanut leaves (Fig. 4A) and stems (Fig. 4B). The results were expected based on effectiveness of these fungicides against stem rot, a soilborne disease caused by $S$. rolfsii, in field research plots and commercial peanut fields.

Basipetal protection was assessed by treating the top three fully expanded leaves with fungicides and then bioassaying nontreated tissues below these leaves with $S$. rolfsii. Stem tissues on which the top leaves were treated with prothioconazole + tebuconazole had decreased necrosis compared with those treated with water when sampled and inoculated 4 days after fungicide treatment (Fig. 5A). The effect was not significant on stems sampled 8 and 12 days following fungicide treatment. Proximal leaves below the treated
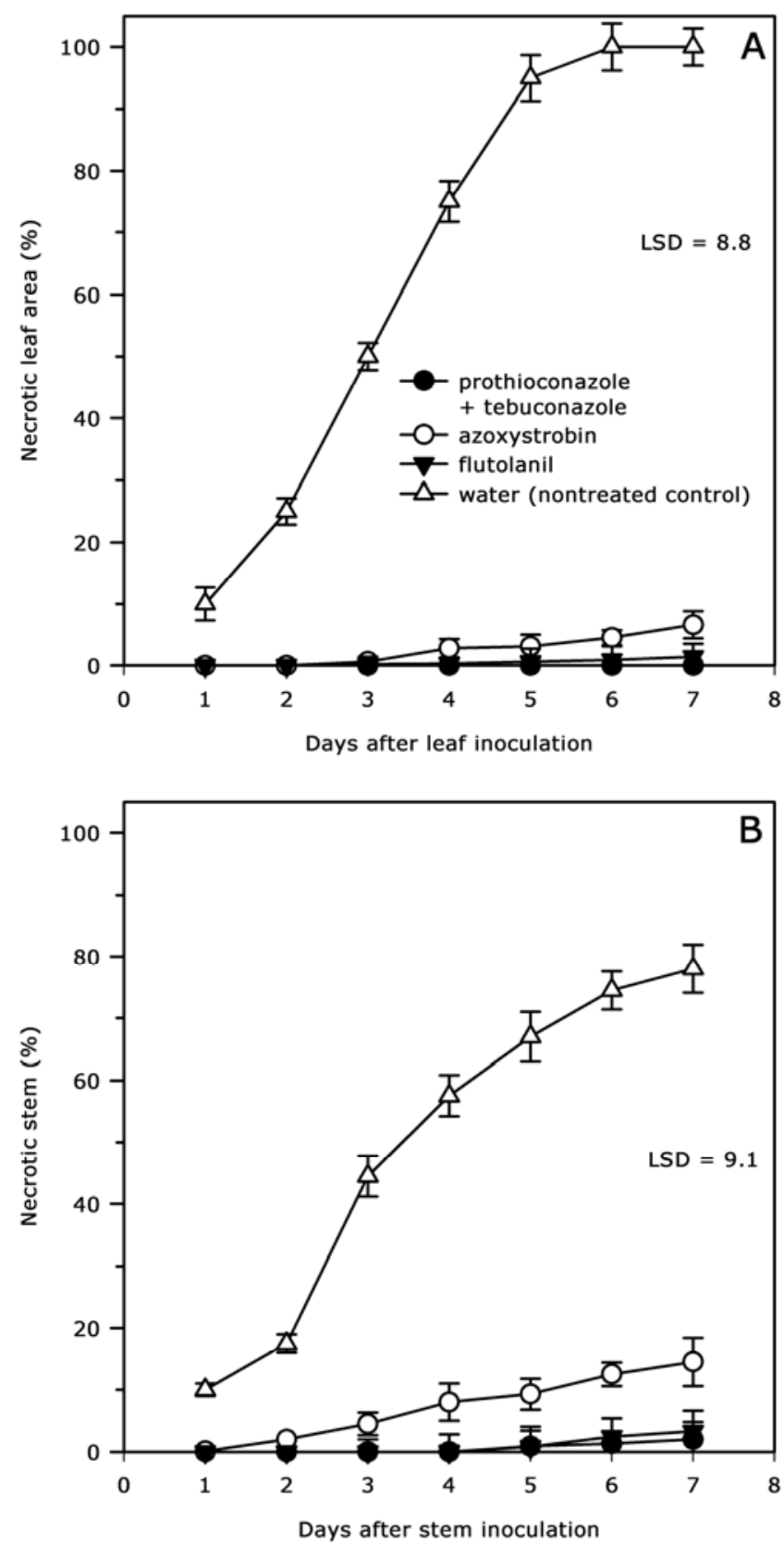

Fig. 4. Fungal colonization of peanut $\mathbf{A}$, leaves and $\mathbf{B}$, stems directly treated with fungicides, then bioassayed with Sclerotium rolfsii. The necrotic leaf area was visually estimated. The percent necrotic stem was derived from measuring the length of necrotic stem.

area, referred to as first-position leaf (Fig. 1), had the most pronounced decrease of necrotic leaf area independent of sampling date with prothioconazole + tebuconazole treatment (Fig. 5B). The early leaf sampling following fungicide treatment had the maximum reduction. The intermediate leaves below the treated area, referred to as second-position leaf (Fig. 1), showed the maximum reduction of necrotic area at 8 days after treatment with prothioconazole + tebuconazole (Fig. 5C). The distal leaves relative to the treated area, referred to as third-position leaf (Fig. 1), had negligible decrease of necrotic leaf area with prothioconazole + tebuconazole at all sampling dates (Fig. 5D). Azoxystrobin and flutolanil did not decrease necrotic tissue on stems (Fig. 5A) and leaves (Fig. 5B-D) below the treated area at any sampling date following inoculation with $S$. rolfsii.

The prothioconazole + tebuconazole applications only slightly affected $S$. rolfsii colonization of pods and pegs at the proximal position (Fig. 6A). Mycelium colonization at the intermediate and 
distal pegs and pods, referred to in Figure 1 as second- and thirdposition peg and pod, respectively, was not affected by prothioconazole + tebuconazole treatment (Fig. 6B and C), and treatment of terminal leaves with azoxystrobin or flutolanil did not affect mycelium colonization at any pod and peg positions (Fig. 6A-C).

Acropetal protection was assessed by bioassaying, with $S$. rolfsii, nontreated new leaves expanding from the tip of stems previously treated with fungicides. All the fungicides decreased the percent necrotic leaf area compared with the water-treated control but fungicide activity was highest with azoxystrobin, followed by prothioconazole + tebuconazole and flutolanil, respectively, from 2 to 7 days after inoculation (Fig. 7).

Greenhouse trials. Statistical analysis showed significant differences in tissue colonization by $S$. rolfsii among fungicide treatments applied to the foliage on main stems when bioassaying proximal and distal leaves from nontreated cotyledonary branches of plants grown in large pots $(P=0.043$ and $P=0.05$, respectively) and small containers $(P=0.018$ and $P=0.027$, respectively).

Peanut plants grown in large pots. Prothioconazole provided more protection of the nontreated leaves in cotyledonary branches when in mixture with tebuconazole than the solo formulation (Table 2). Only in distal cotyledonary leaves did solo prothioconazole provide significant protection compared with cotyledonary leaves from water-treated main stems. None of the fungicides had any effect on the number of fully expanded leaves after fungicide treatment, compared with the water-treated plants. Fungicide treatments of main stem foliage did not affect the colonization by $S$. rolfsii on nontreated cotyledonary stems, roots, pegs, and pods, or the number of formed sclerotia.

Peanut plants grown in small containers. Prothioconazole + tebuconazole applied to the foliage on the main stem provided protection to the nontreated proximal and distal leaves from cotyle-
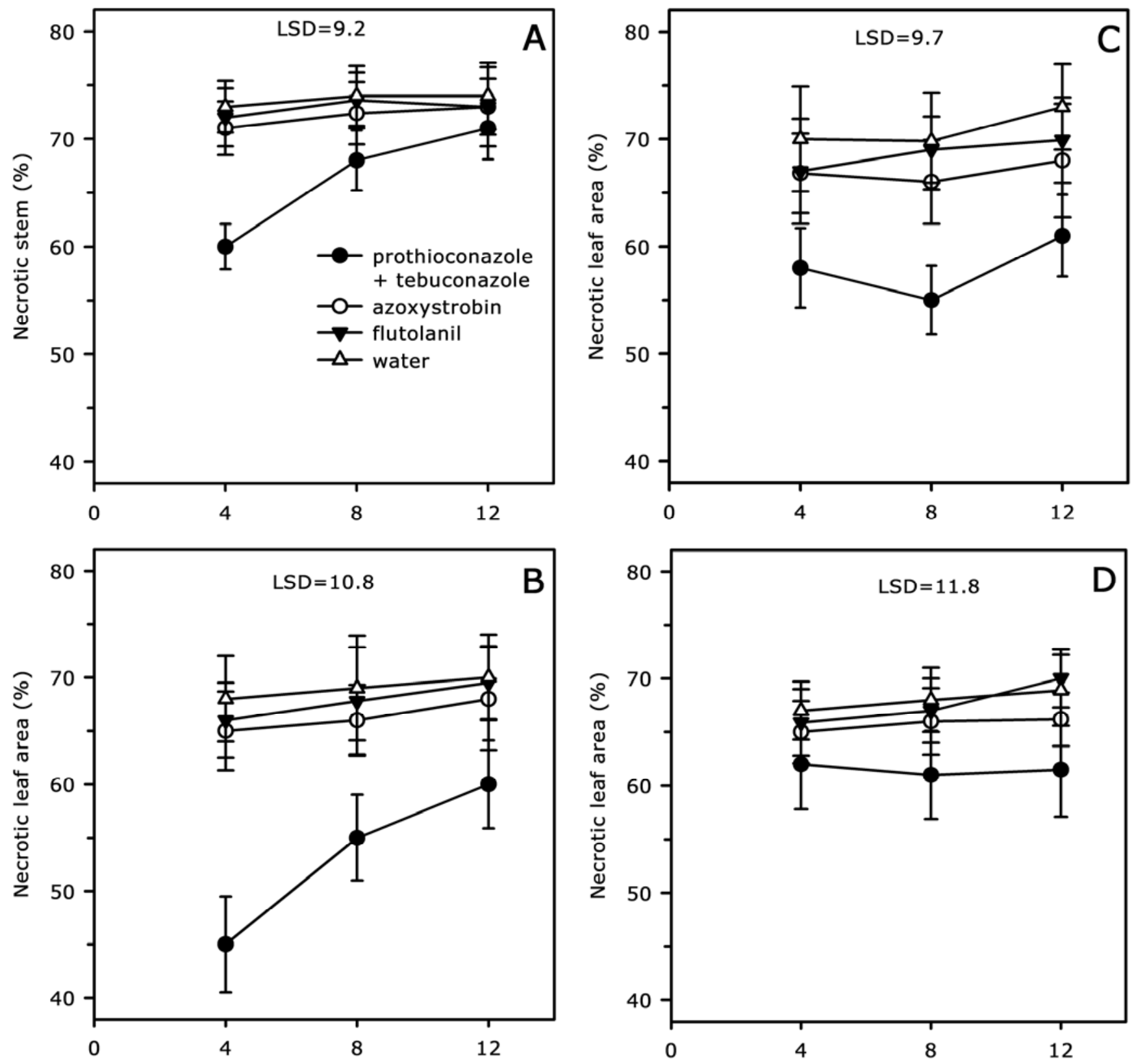

Sampling date (days after treatment)

Sampling date (days after treatment)

Fig. 5. Activity of fungicides over time on nontreated peanut tissues located basipetally to treated stem terminals. Tissues sampled included A, stems; B, first-position leaf; C, second-position leaf; and D, third-position leaf bioassayed by inoculation with Sclerotium rolfsii. Leaves were sequentially numbered from first to third position, with first being the closest to the treated area. Data at each sampling date were assessed 4 days after inoculation. Percent necrotic leaf area was visually estimated and percent necrotic stem area was derived from measuring the necrotic stem length. 
donary branches bioassayed with $S$. rolfsii, and application of solo prothioconazole also protected proximal cotyledonary leaves (Table 3). None of the fungicides applied to the top foliage of the main stems affected plant growth or provided protection to nontreated cotyledonary stems and roots bioassayed with $S$. rolfsii.

\section{Discussion}

Prothioconazole + tebuconazole, azoxystrobin, and flutolanil provided acropetal protection in peanut shoots, implying xylem systemicity. However, prothioconazole + tebuconazole also protected basipetal plant parts. This was seen primarily in the field study where, conceivably, rain or irrigation could have washed surface residues down the stems, to be reabsorbed by the lower stem tissues. Another option is ambimobility (i.e., moving both acropetally and basipetally) of one or both fungicides. The optimum phloem mobility for weakly acidic compounds occurs with $\mathrm{pK}_{\mathrm{a}}$ values of 2 to 6.5 and $\log \mathrm{K}_{\mathrm{ow}}$ between 1 and 3; however, compounds with physicochemical properties outside of these ranges, such as prothioconazole with $\mathrm{pK}_{\mathrm{a}}$ of 6.9 and $\log \mathrm{K}_{\mathrm{ow}}$ of 3.82 , may also have some phloem mobility $(9,41,43)$.
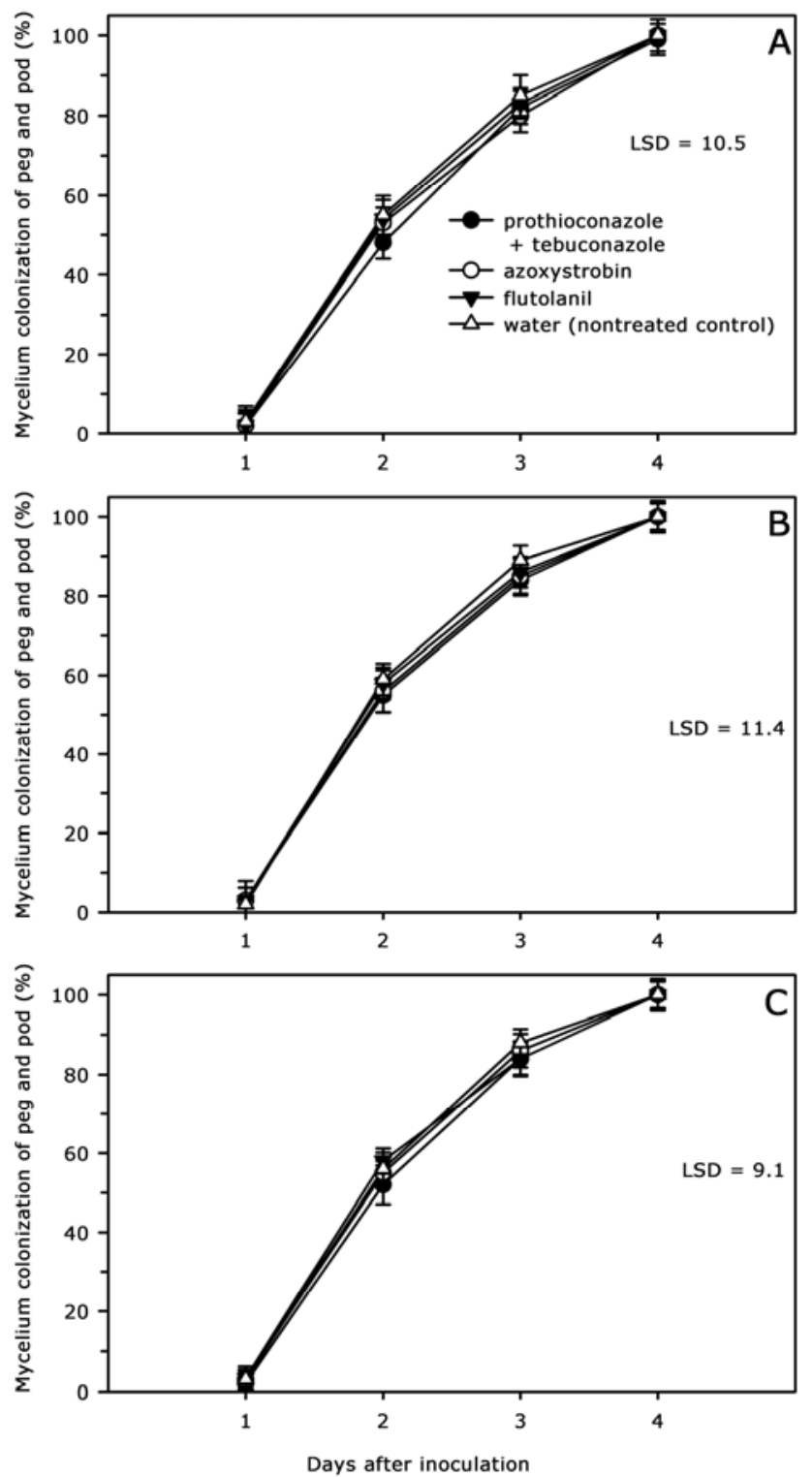

Fig. 6. Systemic activity of fungicides on nontreated $\mathbf{A}$, first-position peg and pod; B, second-position peg and pod; and C, third-position peg and pod. Pods were sequentially numbered from first to third, with third being the farthest to the treated top foliage. Pegs and pods were sampled 12 days after treatment and inoculated with Sclerotium rolfsii.
Tebuconazole, azoxystrobin and flutolanil did not protect plant parts below the treated area at early or late sampling dates. These fungicides are nonacidic and have $\log \mathrm{K}_{\mathrm{ow}}$ values higher than 2 . The optimum $\log \mathrm{K}_{\mathrm{ow}}$ values for phloem mobility of nonionizable compounds are between -3 and 0 (43). The high $\log \mathrm{K}_{\mathrm{ow}}$ values of tebuconazole, azoxystrobin, and flutolanil, together with the apparent protection of new expanding foliage in the field experiments, suggest that these fungicides are nonphloem mobile and translocate in the xylem compartments.

Field and greenhouse experiments showed that prothioconazole (or prothioconazole + tebuconazole) provided protection to the nontreated lower leaves and proximal stem sampled early after fungicide treatment but not to the roots, pods, pegs and distant stems. This could suggest preference in accumulation in leaves compared with other sink parts. The result could also indicate poor phloem mobility or escape from the symplast back to the xylem for upward transport with the transpiration stream to the leaves. The latter theory is supported by a high $\mathrm{pK}_{\mathrm{a}}$ value, which could decrease the dissociated/undissociated ratio and long-distance transport of the fungicide in the phloem. Rapid metabolic degradation of prothioconazole in roots and pods could potentially prevent significant protection as well. This being the case, the risk associated with accumulation of the toxophore in peanut kernels, especially for late application near harvest, will be greatly decreased (32). Ultimately, phloem mobility is the balance between the high permeation needed to gain access into sieve tubes and the low permeation required to remain entrapped during the downward transport (28). From these experiments, the extent of retention of prothioconazole in the sieve tubes is unclear.

Control of plant diseases through vapor activity after application of triazole fungicides has been reported $(13,24,37)$. The degree of contribution from fungicide vapor movement to inhibit fungal growth on untreated, detached plant tissues in these bioassays was not determined and is uncertain.

Although some fungicides, especially triazoles, can alter plant growth and development $(3,10,27,31)$, treatment of peanut foliage with recommended rates of prothioconazole or other fungicides in this study did not affect plant growth, recorded as number of fully expanded leaves following fungicide treatment, even after repeated applications.

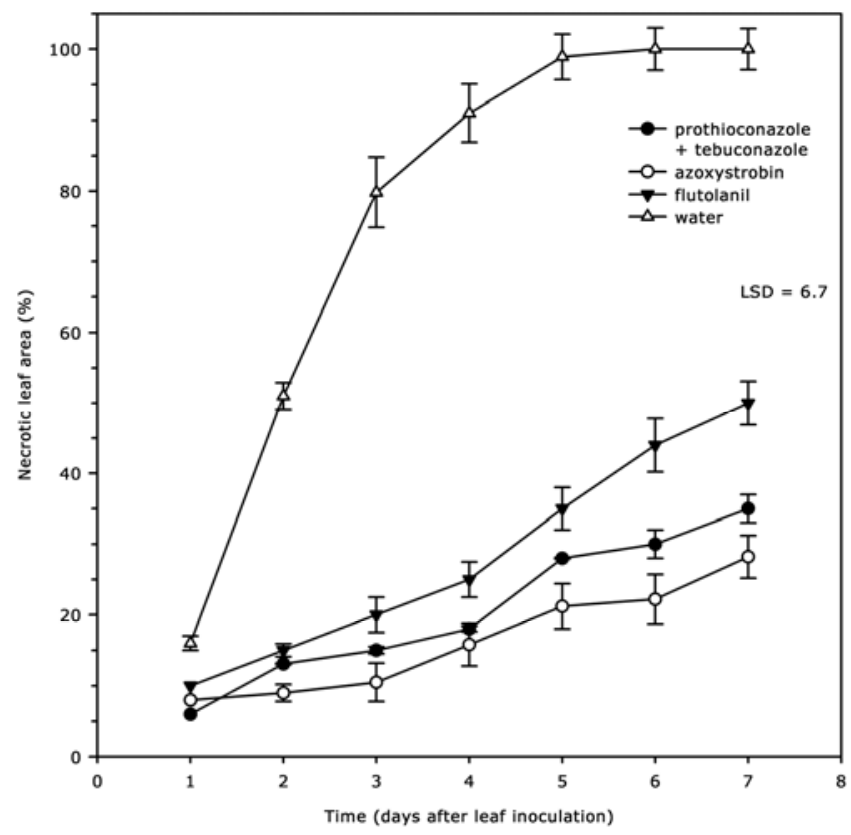

Fig. 7. Systemic activity of fungicides on nontreated, new leaves emerging from stems previously treated with fungicides. New leaves were collected 12 days after treatment and then inoculated with Sclerotium rolfsii. Percent necrotic leaf area was visually estimated. 
Table 2. Systemic activity of fungicides quantified by applying them to main stems of peanut plants grown in the greenhouse, then bioassaying the nontreated, lateral branches with Sclerotium rolfsii (both tissue colonization and sclerotial counts were evaluated)

\begin{tabular}{|c|c|c|c|c|c|c|c|c|c|c|}
\hline \multirow[b]{2}{*}{ Fungicide } & \multirow[b]{2}{*}{ Growth $^{\mathrm{z}}$} & \multicolumn{3}{|c|}{ Necrotic tissue $^{w}$} & \multicolumn{3}{|c|}{ Mycelial colonization $^{x}$} & \multicolumn{3}{|c|}{ Number of sclerotia ${ }^{y}$} \\
\hline & & Proximal $(\%)$ & Distal (\%) & Stem & Root & Peg & Pod & Stem & Root & Pod \\
\hline $\begin{array}{l}\text { Prothioconazole } \\
\text { (Proline } 480 \text { SC, four applications) } \\
\text { Prothioconazole + tebuconazole }\end{array}$ & 13.8 & $70.2 \mathrm{ab}$ & $78.5 \mathrm{ab}$ & 6.6 & 7.1 & 4.0 & 2.8 & 68.8 & 75.7 & 24.0 \\
\hline $\begin{array}{l}\text { (Provost } 433 \mathrm{SC} \text {, four applications) } \\
\text { Tebuconazole }\end{array}$ & 13.6 & $61.7 \mathrm{a}$ & $73.7 \mathrm{a}$ & 6.5 & 6.9 & 4.0 & 2.6 & 88.2 & 66.7 & 23.9 \\
\hline $\begin{array}{l}\text { (Folicur } 3.6 \mathrm{~F} \text {, four applications) } \\
\text { Azoxystrobin }\end{array}$ & 13.7 & $79.2 \mathrm{~b}$ & $85.9 \mathrm{bc}$ & 7.4 & 7.2 & 4.0 & 3.0 & 59.7 & 67.5 & 19.3 \\
\hline $\begin{array}{l}\text { (Abound } 2.08 \mathrm{~F} \text {, two applications) } \\
\text { Flutolanil }\end{array}$ & 13.2 & $74.5 \mathrm{~b}$ & $87.3 \mathrm{bc}$ & 7.2 & 7.3 & 4.0 & 2.9 & 80.0 & 52.2 & 18.9 \\
\hline (Moncut 70W, two applications) & 13.5 & $78.9 \mathrm{~b}$ & $88.8 \mathrm{c}$ & 7.1 & 7.4 & 4.0 & 3.0 & 75.0 & 79.0 & 33.1 \\
\hline None (water, four applications) & 13.4 & $77.5 \mathrm{~b}$ & $88.9 \mathrm{c}$ & 7.4 & 7.3 & 4.0 & 3.0 & 73.5 & 65.2 & 29.4 \\
\hline
\end{tabular}

${ }^{\mathrm{v}}$ Locations on plant: Proximal and Distal $=$ leaves on the lower and upper stems, respectively, of nontreated cotyledonary branches; Stem $=$ lower stem, $0-$

$7.5 \mathrm{~cm} ;$ Root $=$ main root, $0-7.5 \mathrm{~cm} ;$ Peg $=0-4.0 \mathrm{~cm}$; and Pod $=0-3.0 \mathrm{~cm}$.

${ }^{w}$ Data on necrotic leaf area and necrotic stem were visually estimated and measured, respectively, 4 days after the respective plant tissues were inoculated with 3-day-old mycelial plugs of $S$. rolfsii grown on potato dextrose agar. Means within a column followed by different letters are significantly different according to Fisher's protected least significant difference $(P=0.05)$.

${ }^{x} S$. rolfsii mycelium colonization of non-fungicide-treated roots, pegs, and pods was recorded 4 days after inoculation.

${ }^{y}$ Number of formed sclerotia was recorded 4 weeks after inoculation with S. rolfsii.

${ }^{\mathrm{z}}$ Plant growth $=$ number of fully expanded leaves recorded from main stem during the last (fourth) fungicide application.

Table 3. Systemic activity of fungicides quantified by applying them to main stems of peanut plants grown in the greenhouse in small containers, then bioassaying the nontreated, lateral branches with Sclerotium rolfsii ${ }^{\mathrm{w}}$

\begin{tabular}{|c|c|c|c|c|c|}
\hline \multirow[b]{2}{*}{ Fungicide } & \multirow[b]{2}{*}{ Growth $^{y}$} & \multicolumn{3}{|c|}{ Necrotic tissue $^{x}$} & \multirow[b]{2}{*}{$\boldsymbol{R o o t}^{2}$} \\
\hline & & Proximal (\%) & Distal (\%) & Stem & \\
\hline Prothioconazole (Proline 480 SC, four applications) & 9.0 & $71.6 \mathrm{a}$ & $77.2 \mathrm{ab}$ & 7.2 & 6.9 \\
\hline Prothioconazole + tebuconazole (Provost $433 \mathrm{SC}$, four applications) & 8.8 & $73.0 \mathrm{a}$ & $73.8 \mathrm{a}$ & 7.0 & 6.7 \\
\hline Tebuconazole (Folicur 3.6 F, four applications) & 8.9 & $85.2 \mathrm{~b}$ & $85.5 \mathrm{~b}$ & 7.5 & 7.5 \\
\hline Azoxystrobin (Abound $2.08 \mathrm{~F}$, two applications) & 8.6 & $83.6 \mathrm{~b}$ & $84.4 \mathrm{ab}$ & 7.3 & 7.4 \\
\hline Flutolanil (Moncut 70W, two applications) & 8.4 & $86.0 \mathrm{~b}$ & $87.9 \mathrm{~b}$ & 7.5 & 7.5 \\
\hline None (water, four applications) & 8.6 & $85.9 \mathrm{~b}$ & $86.0 \mathrm{~b}$ & 7.5 & 7.5 \\
\hline
\end{tabular}

${ }^{\mathrm{w}}$ Locations: Proximal and Distal = leaves on the lower and upper stems, respectively, of nontreated cotyledonary branches; Stem = lower stem, 0-7.5 $\mathrm{cm}$; and Root $=$ main root, $0-7.5 \mathrm{~cm}$.

${ }^{x}$ Data on necrotic leaf area and necrotic stem were visually estimated and measured, respectively, 4 days after the respective plant tissues were inoculated with 3-day-old mycelial plugs of Sclerotium rolfsii grown on potato dextrose agar. Means within a column followed by the same letters are not significantly different according to Fisher's protected least significant difference $(P=0.05)$.

y Number of fully expanded leaves were recorded from main stem during the last (fourth) fungicide application.

${ }^{\mathrm{z}}$ S. rolfsii mycelium colonization of non-fungicide-treated roots was recorded 4 days after inoculation.

Many studies on systemicity have relied on the chromatographic quantification $(8,11,40)$ or autoradiography $(19,34,43)$ of the phloem sap exudates after leaf, petiole, or stem application of pesticide. Phloem mobility is then quantified as the concentration of the pesticidal compound in the phloem down from the point of application relative to the concentration in the apoplast at the site of application (29). The amount recorded deep in the root zone, stems, or pods, away from application site, may not provide a clear indication of whether the compound will also be biologically active at the intended target site. In addition, these experiments are mostly conducted in younger plants or excised plant parts (20) and, often, some plant species or plant parts are more suitable than others due to difficulties in extracting phloem sap. The fungicide systemicity in younger plants may not correlate with systemic translocation in older plants because the thickness of plant membranes, waxes, distance of translocation, velocity of transpiration stream in the xylem, and chemical composition and flow rate of phloem sap could change with plant age.

The studies reported here do provide direct insights as to the relative systemic protection by several commonly used peanut fungicides. Such information is important in understanding how best to use these fungicides in integrated programs to manage both foliar and soilborne peanut pathogens.

\section{Acknowledgments}

Research funding was provided by the Georgia Peanut Commission. We thank P. Hilton, L. Mullis, R. Griffin, and A. Graham for their support.

\section{Literature Cited}

1. Augusto, J., Brenneman, T. B., Culbreath, A. K., and Sumner, P. 2010 Night spraying peanut fungicides. I. Extended fungicide residual and integrated disease management. Plant Dis. 94:676-682.

2. Augusto, J., Brenneman, T. B., Culbreath, A. K., and Sumner, P. 2010. Night spraying peanut fungicides. II. Application timings and spray deposition in the lower canopy. Plant Dis. 94:683-689.

3. Benton, J. M., and Cobb, A. H. 1995. The plant growth regulator activity of the fungicide, epoxiconazole, on Galium aparine L. (cleaves). Plant Growth Regul. 17:149-155.

4. Boote, K. J. 1982. Growth stages of peanut (Arachis hypogaea L.). Peanut Sci. 9:35-40.

5. Branch, W. D. 1996. Registration of 'Georgia Green' peanut. Crop Sci. 36:806.

6. Brenneman, T. B., and Young, H. 2007. Management of CBR with partially resistant cultivars and prothioconazole. (Abstr.) 2007 Proc. Am. Peanut Res. Educ. Soc. 39:56.

7. Bromilow, R. H., Chamberlain, K., and Evans, A. A. 1990. Physicochemical aspects of phloem translocation of herbicides. Weed Sci. 38:305-314.

8. Bromilow, R. H., Chamberlain, K., and Patil, S. G. 1990. A rapid method using Ricinus communis for the estimation of phloem translocation of xenobiotics. Pestic. Sci. 30:1-12.

9. Brudenell, A. J. P., Baker, D. A., and Grayson, B. T. 1995. Phloem mobility of xenobiotics: tabular review of physicochemical properties governing the output of the Kleier model. Plant Growth Regul. 16:215-231.

10. Buchenauer, H., and Rohner, E. 1981. Effect of triadimefon and triadimenol on growth of various plant species as well as on gibberellin content and sterol metabolism on shoots of barley seedlings. Pestic. Biochem. Physiol. 15:58-70.

11. Chollet, J.-F., Rocher, F., Jousse, C., Deletage-Grandon, C., Bashiardes, G., and Bonnemain, J.-L. 2004. Synthesis and phloem mobility of acidic derivatives of the fungicide fenpiclonil. Pest Manage. Sci. 60:1063-1072. 
12. Cooke, L. R., and Little, G. 2001. The effect of foliar application of phosphonate formulations on the susceptibility of potato tubers to late blight. Pest Manage. Sci. 58:17-25.

13. Coyier, D. L., and Gallian, J. J. 1982. Control of powdery mildew on greenhouse-grown roses by volatilization of fungicides. Plant Dis. 66:842-844.

14. Culbreath, A. K., Brenneman, T. B., Bondari, K., Reynolds, K. L., and McLean, H. S. 1995. Late leaf spot, southern stem rot, and peanut yield responses to rates of cyproconazole and chlorothalonil applied alone and in combination. Plant Dis. 79:1121-1125.

15. Devine, M. D. 1989. Phloem translocation of herbicides. Rev. Weed Sci. 4:191-213

16. Edgington, L. V. 1981. Structural requirements of systemic fungicides. Annu. Rev. Phytopathol. 19:107-124.

17. Grayson, B. T., and Kleier, D. A. 1990. Phloem mobility of xenobiotics. IV. Modeling of pesticide movement in plants. Pestic. Sci. 30:67-79.

18. Griffin, G. J., and Tomimatsu, G. S. 1983. Root infection pattern, infection efficiency, and infection density-disease incidence relationships of $\mathrm{Cyl}$ indrocladium crotalariae on peanut in field soil. Can. J. Plant Pathol. 5:8188.

19. Grimm, E., Grube, A., Jahnke, S., and Neumann, S. 1995. Retention of xenobiotics along the phloem path. Planta 197:11-18.

20. Hoad, G. V. 1980. A simple system for determining phloem mobility of compounds using excised pods of lupin (Lupinus album L.). Planta 150:275-278.

21. Holbrook, C. C., and Culbreath, A. K. 2007. Registration of Tifrunner peanut. J. Plant Regist. 1:124.

22. Hsu, F. C., and Kleier, D. A. 1996. Phloem mobility of xenobiotics. VIII. A short review. J. Exp. Bot. 47:1265-1271.

23. Hsu, F. C., Sun, K., Kleier, D. A., and Fielding, M. J. 1995. Phloem mobility of xenobiotics VI. A Phloem-mobile pronematicide based on oxamyl exhibiting root-specific activation in transgenic tobacco. Pestic. Sci. 44:9-19.

24. Jenkyn, J. F., Dyke, G. V., and Todd, A. D. 1983. Effects of fungicide movement between plots in field experiments. Plant Pathol. 32:311-324.

25. Kemerait, B., Brenneman, T., and Culbreath, A. 2010. 2010 peanut disease update. Pages 57-80 in: 2010 Peanut Update. J. P. Beasley, Jr., ed. Coop. Ext. Serv. Coll. Agric. Environ. Sci., University of Georgia.

26. Kempe, G. 2003. Multi-residue methods (S19) to measure azole fungicides in crop samples. Pages 1099-1127 in: Handbook of Residue Analytical Methods for Agrochemicals, vol. 2. P. W. Lee, ed. John Wiley \& Sons Ltd., West Sussex, England.

27. Khalil, I. A., Mercer, E. I., and Wang, Z. X. 1990. Effect of triazole fungicides on the growth, chloroplast pigments and sterol biosynthesis of maize (Zea mays L.). Plant Sci. 66:21-28.

28. Kleier, D. A. 1988. Phloem mobility of xenobiotics. I. Mathematical model unifying the weak acid and intermediate permeability theories. Plant
Physiol. 86:803-810.

29. Kleier, D. A., Grayson, B. T., and Hsu, F. C. 1998. The phloem mobility of pesticides. Pestic. Outlook 9:26-30.

30. Kobayashi, H. 2003. Aniles. Pages 327-343 in: Handbook of Residue Analytical Methods for Agrochemicals, vol. 1. P. W. Lee, ed. John Wiley \& Sons Ltd., West Sussex, England.

31. Koller, W. 1987. Isomers of sterol synthesis inhibitors: fungicidal effects and plant growth regulator activities. Pestic. Sci. 18:129-147.

32. Lichtner, F. 2000. Phloem mobility of crop protection products. Aust. J. Plant Physiol. 27:609-614.

33. Navarro, S. Fenoll, J., Vela, N., Ruiz, E., and Navarro, G. 2009. Photocatalytic degradation of eight pesticides in leaching water by use of $\mathrm{ZnO}$ under natural sunlight. J. Hazard. Mater. 172:1303-1310.

34. Neumann, S., Grimm, E., and Jacob, F. 1985. Transport of xenobiotics in higher plants. I. Structural prerequisites for translocation in the phloem. Biochem. Physiol. Pflanz. 180:257-268.

35. O'Keefe, B., Funk, S., and Goodlow, T. 2007. Prothioconazole: human health risk assessment for proposed uses on barley, canola, chickpea, dried shelled peas and beans (except soybean), lentils, oilseed crops (except sunflower and safflower), peanut, wheat, and rice. Petition No. 4F6830. EPA, Washington, DC 20460

36. Otakie, G. F. 1991. New chemical: tebuconazole fungicide on peanuts, grapes, wheat, barley, oat and seed grass. Evaluation of analytical methods, residue, and processing data. Petition No. 9F3724/9F03818 and FAP No. 9H5575. EPA, Washington, DC 20460.

37. Pearson, R. C., Riegel, D. G., and Gadoury, D. M. 1994. Control of powdery mildew in vineyards using single-application vapor-action treatments of triazole fungicides. Plant Dis. 78:164-168.

38. Phipps, P. M., and Beute, M. K. 1977. Influence of soil temperature and moisture on the severity of Cylindrocladium black rot in peanut. Phytopathology 67:1104-1107.

39. Quimette, D. G., and Coffey, M. D. 1990. Symplastic entry and phloem translocation of phosphonate. Pestic. Biochem. Physiol. 38:18-25.

40. Rigitano, R. L. O., Bromilow, R. H., Briggs, G. G., and Chamberlain, K. 1987. Phloem translocation of weak acids in Ricinus communis. Pestic Sci. 19:113-133

41. Smith, P. H, Chamberlain, K., Sugars, J. M, and Bromilow, R. H. 1995. Fungicidal activity of $\mathrm{N}$-(2-cyano-2-methoximinoacetyl) amino acids and their derivatives. Pestic. Sci. 44:219-224.

42. Woodward, J. E. 2006. Optimizing efficacy and economic benefits of fungicides for peanut disease control via pre-plant analysis of disease risk and irrigation timing. Ph.D. dissertation, University of Georgia, Athens.

43. Wright, K. M., Prior, D. A. M., and Oparka, K. J. 1994. Observations on the accumulation of five xenobiotic chemicals in phloem versus parenchyma tissues of celery. Pestic. Sci. 42:17-24. 